\title{
Precipitation of manganese oxides on the surface of construction materials in the Khmer temples, Cambodia
}

\author{
Etsuo Uchida ${ }^{*}$, Ryota Watanabe ${ }^{1}$ and Satomi Osawa ${ }^{2}$
}

\begin{abstract}
Background: In addition to the blackening caused by blue-green algae growth, other black areas on the surface of construction materials (e.g., sandstone, laterite and bricks) are frequently observed in the Khmer temples in Cambodia. A non-destructive on-site investigation was carried out using a portable X-ray fluorescence analyzer (pXRF). In addition, samples were taken from the buildings and were analyzed using an X-ray diffractometer (XRD) and a scanning electron microscope with an energy dispersive $X$-ray spectrometer, and were observed using a field emission scanning electron microscope.

Results and conclusions: A non-destructive investigation using the pXRF revealed that this blackening was caused by manganese oxide precipitates. The precipitates contained small amounts of $\mathrm{Ni}, \mathrm{V}, \mathrm{Zn}, \mathrm{Y}, \mathrm{K}, \mathrm{Cl}, \mathrm{S}, \mathrm{Pb}$, and $\mathrm{Cr}$. The XRD analysis indicated that the manganese oxides were mainly present as an amorphous phase, but some formed birnessite and todorokite. The manganese precipitates were mostly in a hexagonal plate form (100-300 nm), but some were in a rod-shape, which may have been caused by the activity of manganese oxidizing microbes. Preliminary experiments on removal of manganese oxide precipitates were conducted. The manganese oxide precipitates could be easily removed using a reducing agent such as an oxalic acid solution.
\end{abstract}

Keywords: Manganese oxide, Manganese oxidizing microbe, Birnessite, Todorokite, Khmer temple, Cambodia

\section{Background}

Sandstone, laterite and bricks were the major construction materials used by the Khmer people in their temples, including the Angkor monuments in Cambodia during the ninth to fifteenth centuries $[1,2]$. With the passage of time, the surfaces of these materials have blackened. Most of this discoloring is caused by blue-green algae (cyanobacteria), which gradually damage the bas-relief carvings on these temples [3]. In addition, black areas with more luster than the blue-green algae are frequently observed on the surface of the construction materials in the Khmer temples. Similar blackening has been also observed on the surface of Mesopotamian clay tablets, and analysis indicated that this was caused by manganese

\footnotetext{
*Correspondence: weuchida@waseda.jp

1 Department of Resources and Environmental Engineering, Waseda

University, Ohkubo 3-4-1, Shinjuku-ku, Tokyo 169-8555, Japan

Full list of author information is available at the end of the article
}

oxide precipitates [4]. This is similar to desert varnish, which contains manganese and iron oxides and is found on stone surfaces in the desert [5-7]. To date, no study has been conducted to investigate if the blackening on the Khmer temples is caused by manganese oxide precipitates. Although this black material does not seem to damage the construction materials, it has changed the color of the temples so they no longer appear as they did in their original condition. To prevent further blackening, this study aimed to determine if the blackening on the surface of construction materials in the Khmer temples is caused by precipitation of manganese oxides, and also to elucidate the precipitation mechanism.

A non-destructive on-site investigation was carried out using a portable X-ray fluorescence analyzer (pXRF). In addition, samples were taken from the buildings and analyzed using an X-ray diffractometer (XRD) and a scanning electron microscope with an energy-dispersive 
$\mathrm{X}$-ray spectrometer (SEM-EDX), and examined using a field emission scanning electron microscope (FE-SEM).

\section{Methods}

\section{Sample site}

The investigation was carried out at the Angkor, Koh Ker and Sambor Prei Kuk monuments in Cambodia, which were selected as sites that were representative of the Khmer monuments (Fig. 1). The Angkor monuments are located $250 \mathrm{~km}$ northwest of Phnom Penh, the capital of Cambodia. They were constructed during the ninth to fifteenth centuries. The Koh Ker monuments are located $85 \mathrm{~km}$ northeast of the Angkor monuments. This site was the capital of the Khmer empire from 921 to 944 AD. The Sambor Prei Kuk monuments are located $140 \mathrm{~km}$ southeast of the Angkor monuments, and construction at this site occurred in the pre-Angkorian period. The Sambor Prei Kuk monuments were the capital in the seventh century.

Blackening, suspected to be from manganese oxide precipitates, is observed on the surface of all types of construction materials used in the Khmer temples, including sandstone (feldspathic sandstone and siliceous sandstone), laterite, and bricks. This discoloration is extensive on the surface of laterite at the Koh Ker monuments, especially on the Neang Khmau (Fig. 2a), Chrap (Fig. 2b), and Banteay Pir Chan (Fig. 2c, d) temples. Blackening is also evident on the surfaces of bricks and sandstone used in the southern brick towers situated on the eastern side of the Pre Rup temple at the Angkor monuments (Fig. 2e, f). Also at the Angkor monuments, there is blackening on the east side of the north face of the inner gallery of the Bayon temple (Fig. 2g). At the Sambor Prei Kuk monuments, there are black areas on the walls of the towers $\mathrm{C} 1$ (Fig. 2h) and S1 (Fig. 2i). Black areas are observed on both the inner and outer surfaces of the buildings (Fig. 2d, f). In addition to these sites, blackening is frequently observed at other Khmer architectural sites.

\section{Analytical methods}

The black materials, which were thought to be manganese oxide precipitates, were analyzed non-destructively onsite using a pXRF analyzer (Delta Premium, Innov-X Systems, Waltham, MA, USA) with an X-ray tube with a Rh target $(4 \mathrm{~W})$. The analysis was conducted in a soil mode

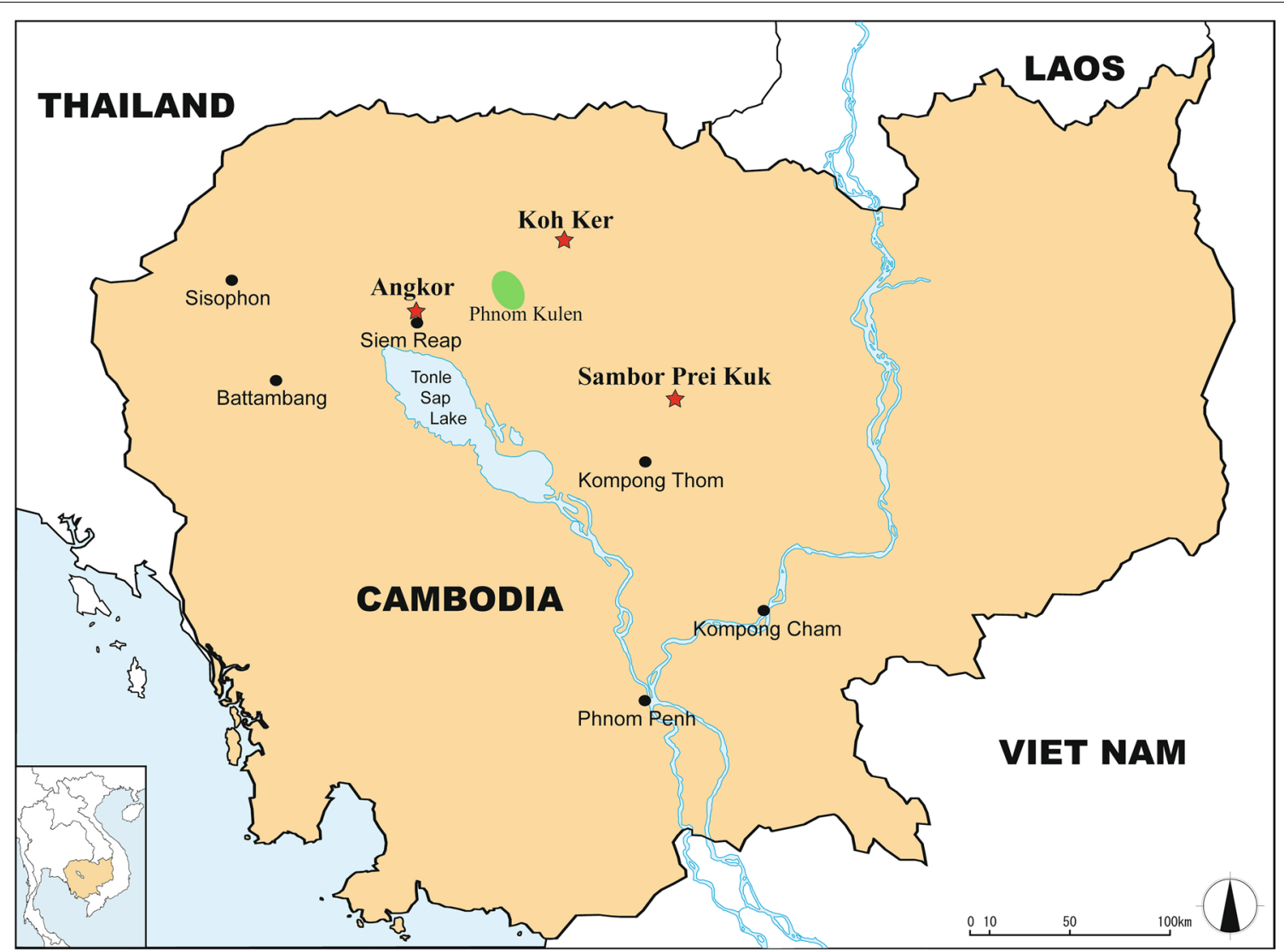

Fig. 1 Map showing the locations of the Angkor, Koh Ker, and Sambor Prei Kuk monuments in Cambodia 


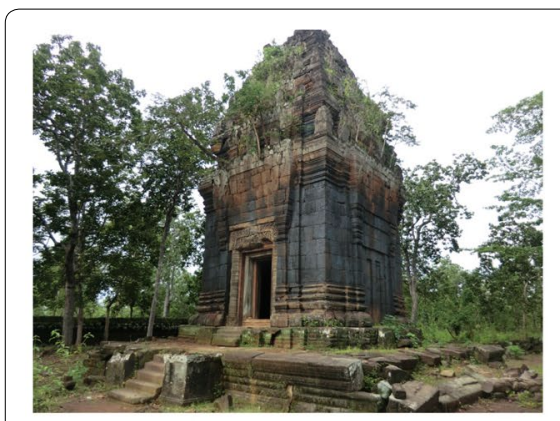

a Pr. Neang Khmau

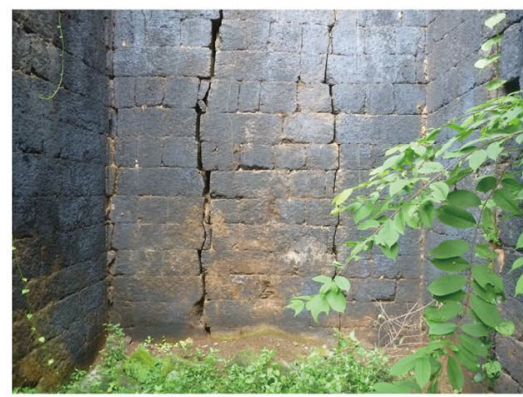

d Pr. Banteay Pir Chan (Inner wall)

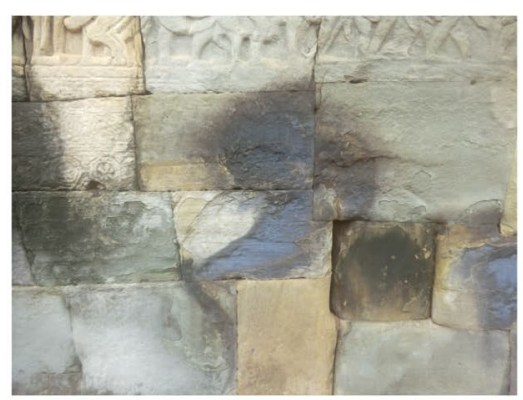

g Bayon (Inner gallery)

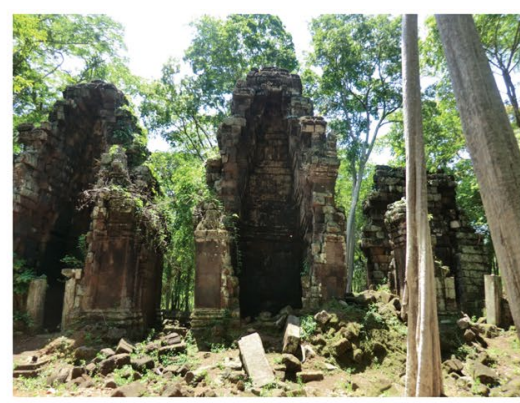

b Pr. Chrap

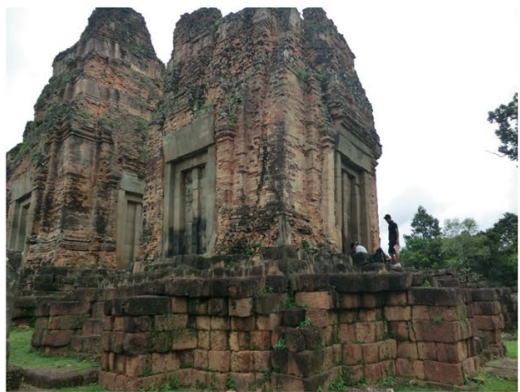

e Pre Rup

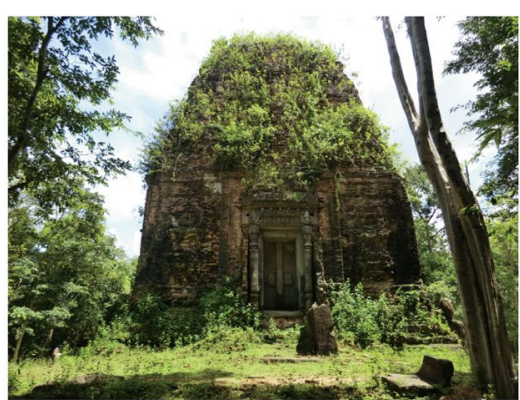

h Sambor Prei Kuk C1

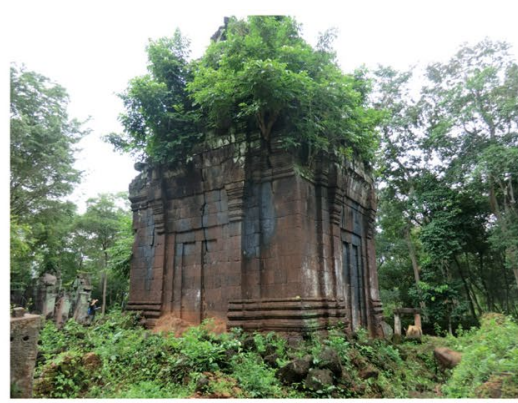

c Pr. Banteay Pir Chan

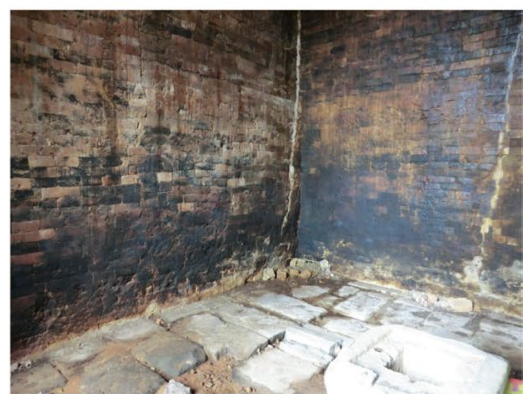

f Pre Rup (Inner wall)

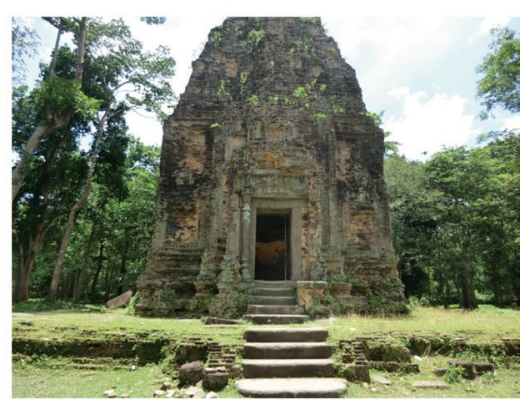

i Sambor Prei Kuk S1

Fig. 2 Photographs showing blackening suspected to be from manganese oxide precipitates on the surfaces of construction materials in the Khmer temples at the following sites: a Neang Khmau, b Chrap, c Banteay Pir Chan, d Banteay Pir Chan (inner wall), e Pre Rup, f Pre Rup (inner wall), $\mathbf{g}$ Bayon (inner gallery), $\mathbf{h}$ the tower C1 at the Sambor Prei Kuk monuments, and $\mathbf{i}$ the tower S1 at the Sambor Prei Kuk monuments

for $60 \mathrm{~s}$ at each point. Before analysis, the pXRF analyzer was calibrated for $\mathrm{Mn}, \mathrm{Ni}, \mathrm{V}, \mathrm{Zn}, \mathrm{K}, \mathrm{Pb}, \mathrm{Cr}, \mathrm{Sr}, \mathrm{Cu}, \mathrm{Ti}, \mathrm{Rb}$, $\mathrm{Ca}, \mathrm{Fe}$ and $\mathrm{Zr}$ using 10 rock standards obtained from the Geological Survey of Japan [8]. However the analysis for the black materials may be semi-quantitative because the black materials are as thin as less than $0.2 \mathrm{~mm}$ and X-ray penetrates into the under layer such as sandstone, laterite and bricks. Analyses were conducted on the blackened areas of the construction materials and also on nonblackened areas of the construction materials as controls. Five points were analyzed at each building, and the average values were calculated.

Construction materials covered with black materials were also taken from the buildings (sample nos. 34013414 in Table 1). The samples were taken from different places, which were analyzed using the pXRF analyzer. The black materials on the surface of the samples were removed using a drill. The samples of the black materials were analyzed using an XRD (RINT-RAPID, Rigaku, Tokyo, Japan) with an X-ray tube with a $\mathrm{Cu}$ target. The current and voltage were $30 \mathrm{~mA}$ and $40 \mathrm{kV}$, respectively. Each scan was conducted from $2 \theta=2^{\circ}-60^{\circ}$ with a scan speed of $1 \%$ min.

The black materials were also analyzed using a SEMEDX (JSM6360, JEOL, Tokyo, Japan equipped with Inca Energy, Oxford Instruments, Abingdon, UK). The SEMEDX analysis was conducted on a polished cross section of each sample. Samples for the SEM-EDX were first embedded in an epoxy resin (EpoFix, Struers, Ballerup, Denmark), and then polished with waterproof SiC paper (\#180, 
Table 1 List of the samples of black materials taken from the Khmer temples

\begin{tabular}{|c|c|c|c|}
\hline Sample no. & Base material & Temple & Sampling point \\
\hline 3401 & Sandstone & Bayon & East side of the north face of the inner gallery \\
\hline 3402 & Laterite & Prasat Neang Khmau & Outer wall of the central tower \\
\hline 3403 & Laterite & Prasat Chrap & Inner wall of the southern tower \\
\hline 3404 & Laterite & Prasat Banteay Pir Chan & Inner wall of the central tower \\
\hline 3405 & Laterite & East Mebon & Northwestern library \\
\hline 3406 & Laterite & Pre Rup & Outer wall of the inner enclosure \\
\hline 3407 & Sandstone & Pre Rup & Outer wall of the southernmost tower in the east towers \\
\hline 3408 & Laterite & Ta Keo & Second platform \\
\hline 3409 & Laterite & Phnom Krom & Outer wall of the enclosure \\
\hline 3410 & Laterite & Wat Athvea & Inner wall of the enclosure \\
\hline 3411 & Bricks & Sambor Prei Kuk & Outer wall of the tower S1 \\
\hline 3412 & Sandstone & Sambor Prei Kuk & Outer wall of the tower S1 \\
\hline 3413 & Bricks & Sambor Prei Kuk & Outer wall of the tower $\mathrm{C} 1$ \\
\hline 3414 & Sandstone & Sambor Prei Kuk & Outer wall of the tower $\mathrm{C} 1$ \\
\hline
\end{tabular}

$\# 800$, \#1200, and \#2400 $\mu \mathrm{m}$, Struers) and diamond paste ( $3 \mu \mathrm{m}$, Struers). Finally, the samples were coated with carbon. The accelerating voltage was $15 \mathrm{kV}$, and the beam current was adjusted so that the X-ray count was 2000 count/s on the Co surface. The measurement time was $60 \mathrm{~s}$.

In addition, the surface of each black material sample was examined using a FE-SEM (4500S, Hitachi, Tokyo, Japan). The accelerating voltage was $15 \mathrm{kV}$, and the sample surface was coated with platinum-palladium $\left(\mathrm{Pt}_{80} \mathrm{Pd}_{20}\right)$.

\section{Results and discussion pXRF analysis}

Because the pXRF analysis was conducted in the air and in a soil mode, light elements such as $\mathrm{Na}, \mathrm{Mg}, \mathrm{Al}$ and $\mathrm{Si}$ which are major components of rocks, could not be analyzed. The pXRF results for the average chemical compositions at each building are summarized in Table 2 . The ratio of each element in the black area to that in the non-black area is shown in Fig. 3. This shows that Mn was highly concentrated in the black areas $(22,700$ $247,000 \mathrm{mg} / \mathrm{kg}$ ) compared to the non-black areas. In addition, $\mathrm{Ni}, \mathrm{V}, \mathrm{Zn}, \mathrm{Y}, \mathrm{K}, \mathrm{Cl}, \mathrm{S}, \mathrm{Pb}$, and $\mathrm{Cr}$ were also concentrated in the black areas compared with the non-black areas. The average $\mathrm{V}$ content range was $1000-10,800 \mathrm{mg} /$ $\mathrm{kg}$, except for the tower C1 (sandstone) at the Sambor Prei Kuk monuments. The Ni content was high at the Koh Ker monuments (1400-2800 mg/kg). The $\mathrm{Zn}$ and $\mathrm{Cr}$ contents were high at the tower S1 at the Sambor Prei Kuk monuments, with concentrations of $2400 \mathrm{mg} / \mathrm{kg}(\mathrm{Zn})$ and $6000 \mathrm{mg} / \mathrm{kg}(\mathrm{Cr})$ recorded on bricks and $850 \mathrm{mg} / \mathrm{kg}(\mathrm{Zn})$ and $3600 \mathrm{mg} / \mathrm{kg}(\mathrm{Cr})$ on sandstone. The Fe content in the black areas was similar to that in the non-black areas. The
Mn content is generally less than $0.3 \%$ in sandstone, laterite, and bricks $[1,2]$. However, laterite at the Koh Ker monuments contains more Mn (0.3-2.4 \%) [9]. This may be one of the reasons why precipitation of manganese oxides is remarkable on the surface of laterite at the Koh Ker monuments.

The enrichment of $\mathrm{Mn}, \mathrm{Ni}, \mathrm{V}, \mathrm{Zn}, \mathrm{Y}, \mathrm{Pb}$, and $\mathrm{Cr}$ in ferromanganese crusts against seawater was reported by Hein et al. [10]. In addition, the enrichment of $\mathrm{K}, \mathrm{Ni}, \mathrm{Zn}$ and $\mathrm{Pb}$ in rock varnish was reported by Dorn et al. [11]. The enrichment of $\mathrm{Cl}$ and $\mathrm{S}$ in the manganese oxides on the surface of the construction materials in the Khmer monuments may be attributable to bat guano [12].

\section{SEM-EDX analysis}

The black materials obtained from the different sites were less than $0.2 \mathrm{~mm}$ thick, but in some cases as thick as $0.5 \mathrm{~mm}$ (Fig. 4). The results from chemical analyses of these samples by the SEM-EDX are summarized in Table 3. In addition, SEM and X-ray images in the cross section of sample no. 3405 from the inner wall of East Mebon were shown in Fig. 4. The dominant element in the black areas was $\mathrm{Mn}$, with a range of $4-48 \%$. Compared with the non-black areas, Mn was 10-390 times more concentrated in the black areas. The $\mathrm{Al}, \mathrm{Si}$, and $\mathrm{Fe}$ content ranges in the black areas were 3-19,3-34, and 2-52 \%, respectively. These elements could be attributed to the construction materials. $\mathrm{P}$ is distributed just on the surface of construction materials and is covered by black materials (Fig. 4). P is considered to have been derived from bat excrement. Trace elements detected by the pXRF such as $\mathrm{Ni}, \mathrm{V}, \mathrm{Zn}, \mathrm{Y}, \mathrm{Pb}$, and $\mathrm{Cr}$ were not detected by the SEM-EDX because these elements were contained 


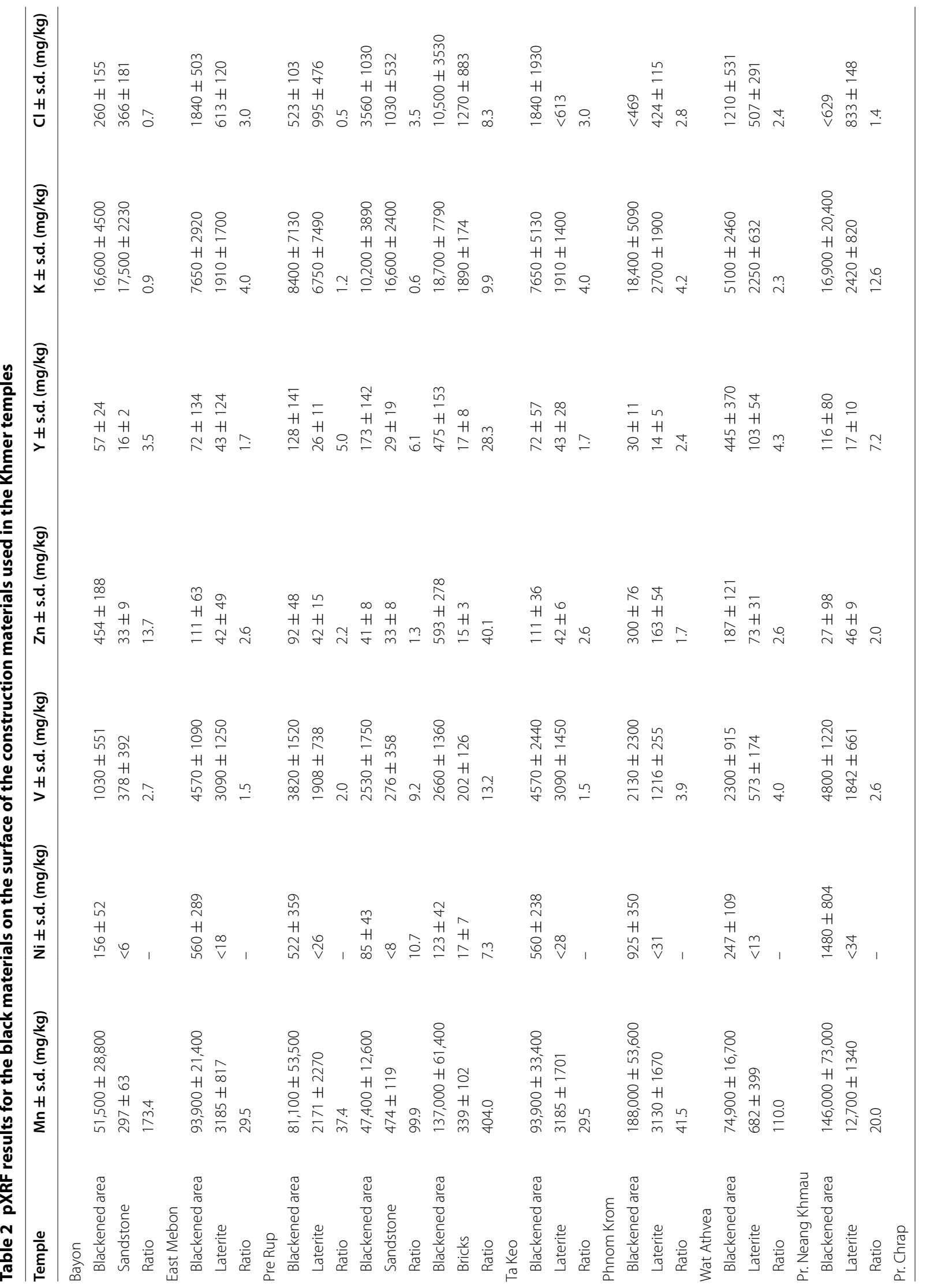




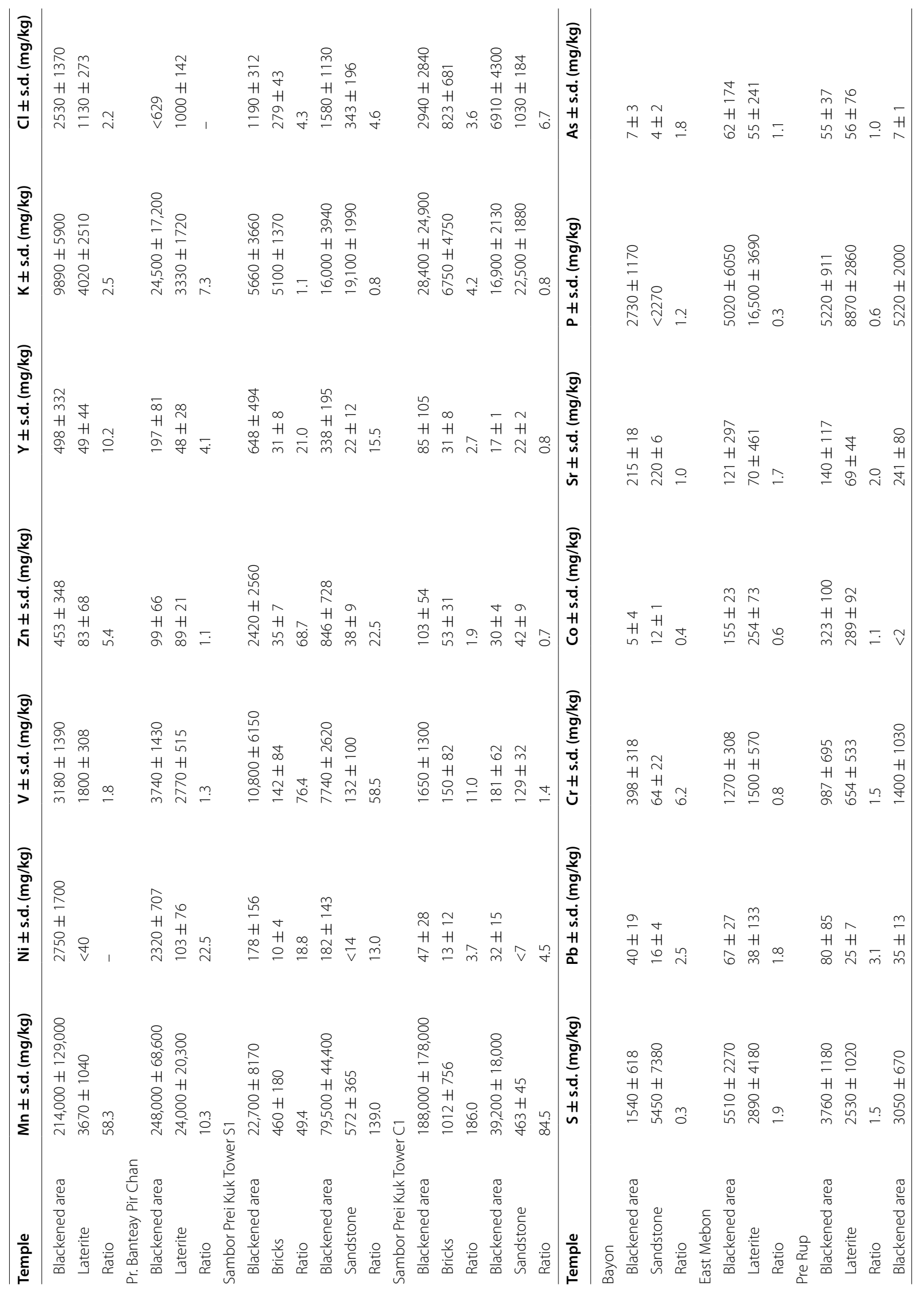




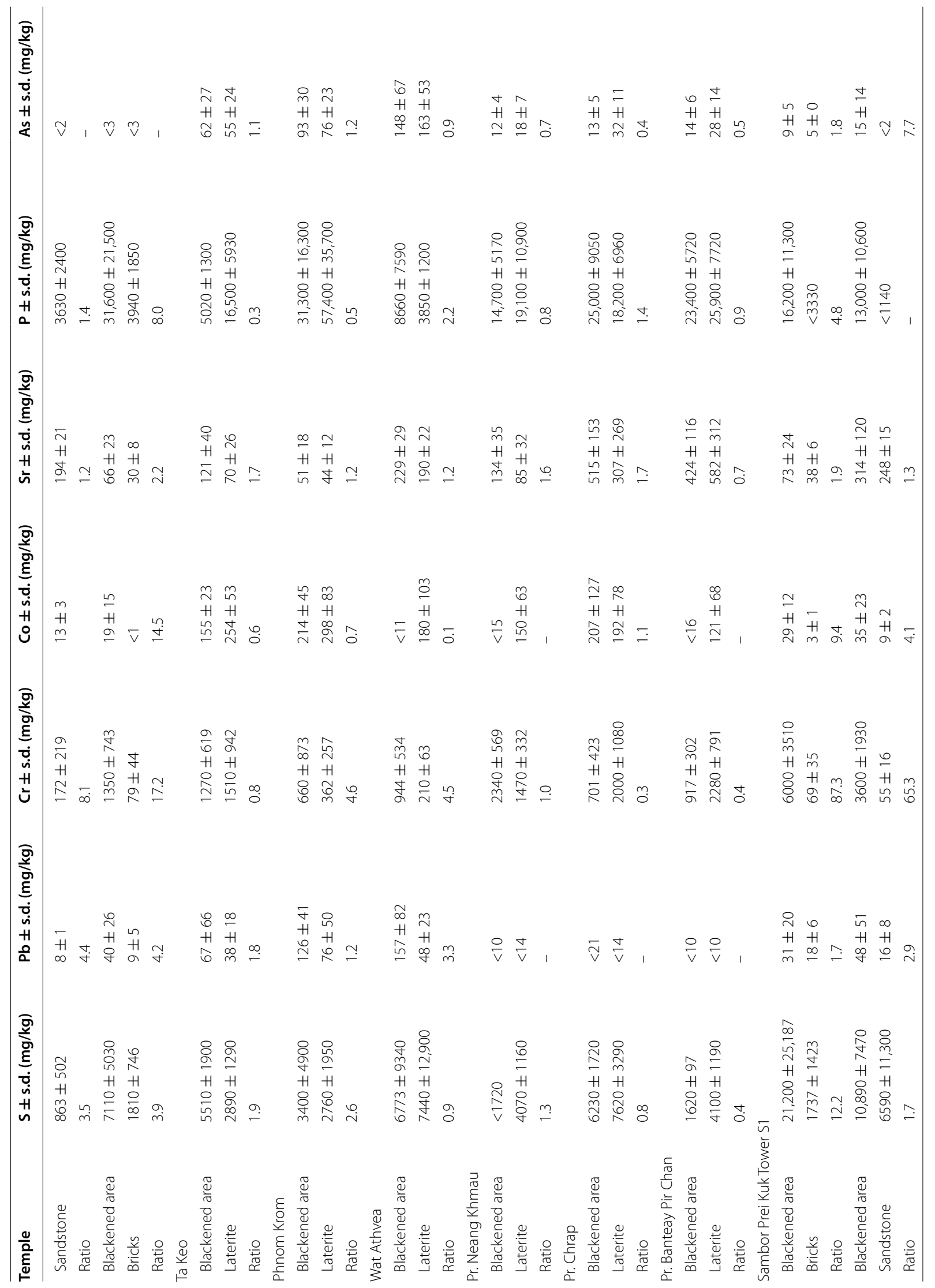




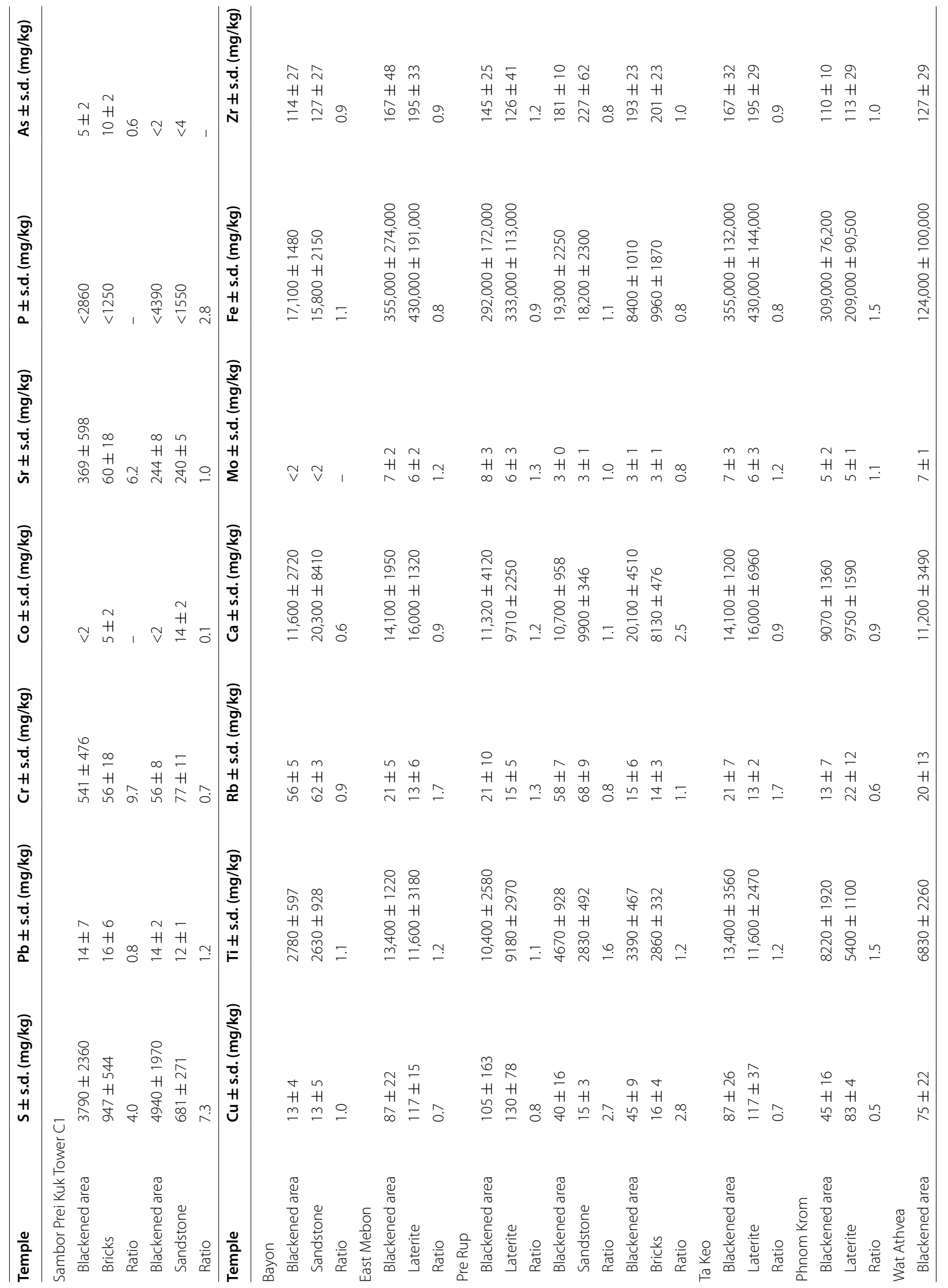




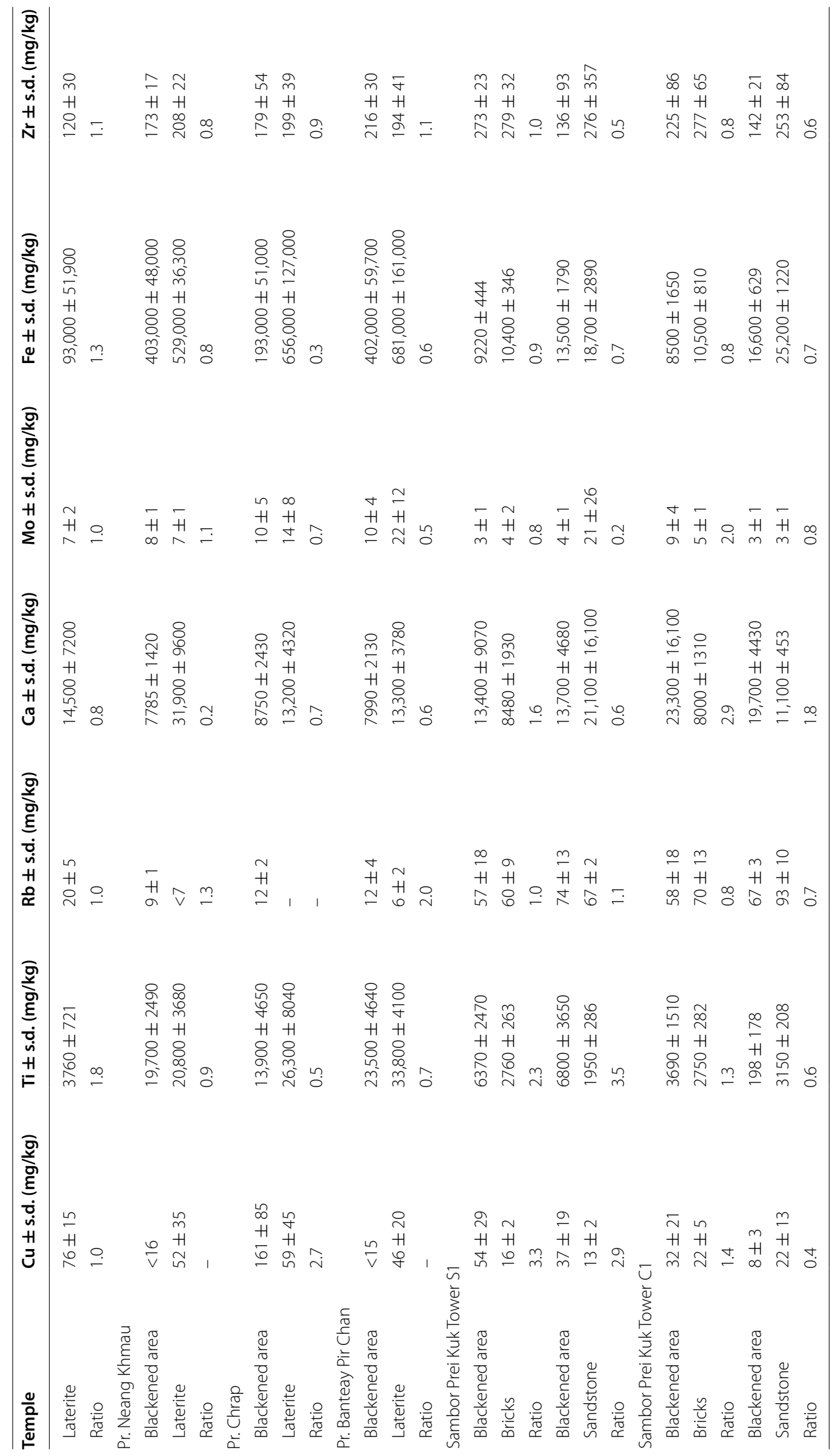




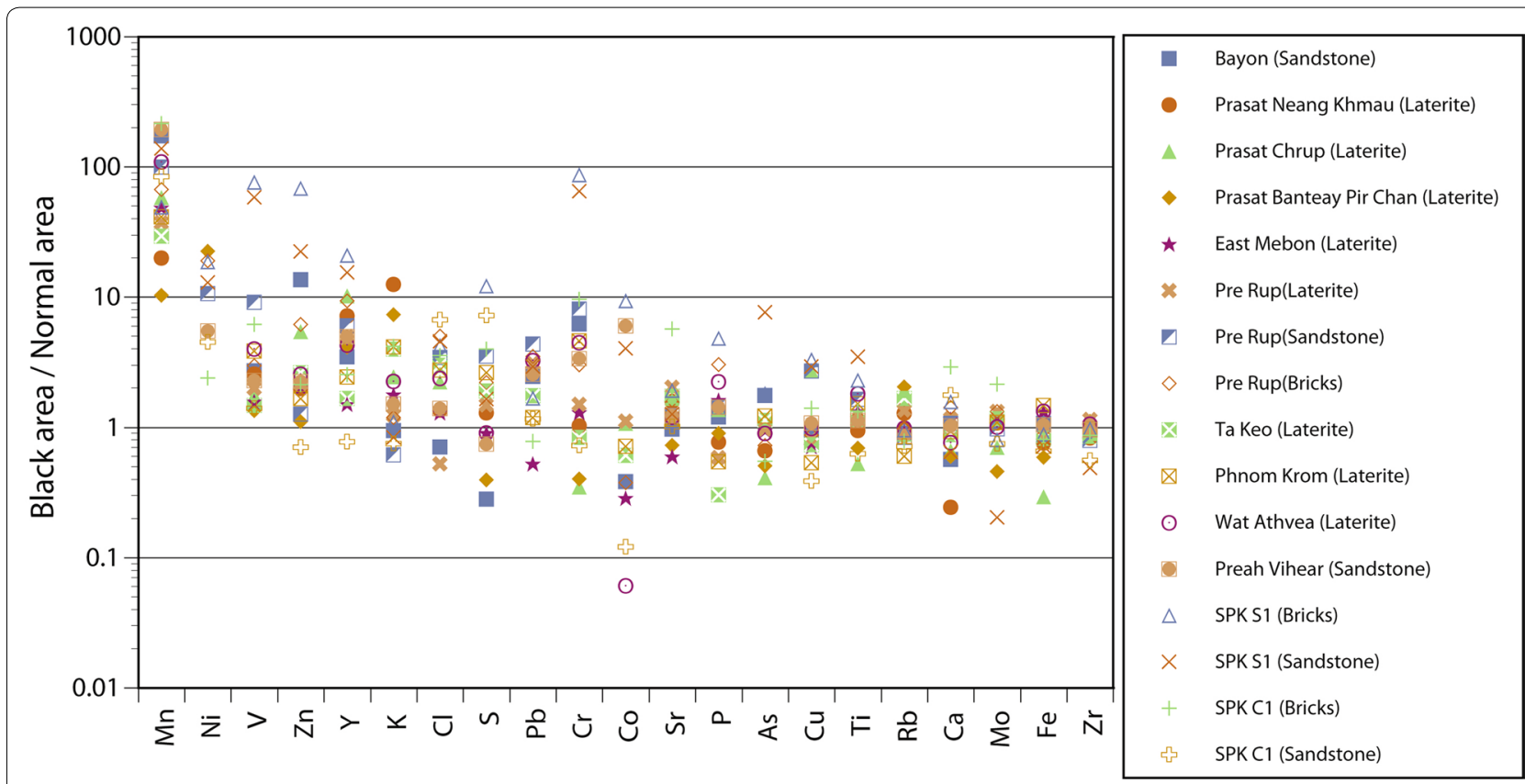

Fig. 3 pXRF results expressed as ratios for the concentrations of the elements in the black area to those in the non-black area on the surface of construction materials in the Khmer temples

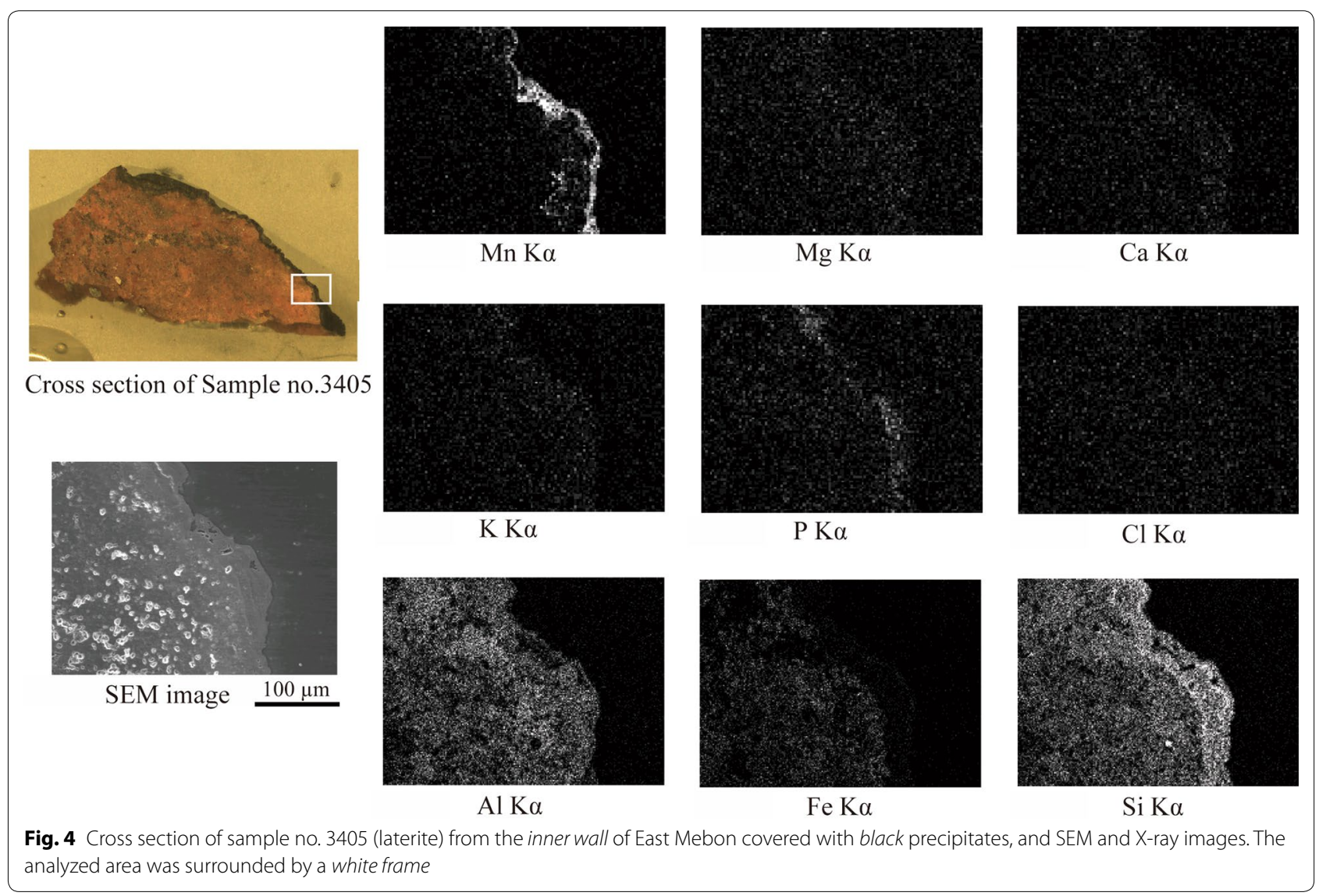




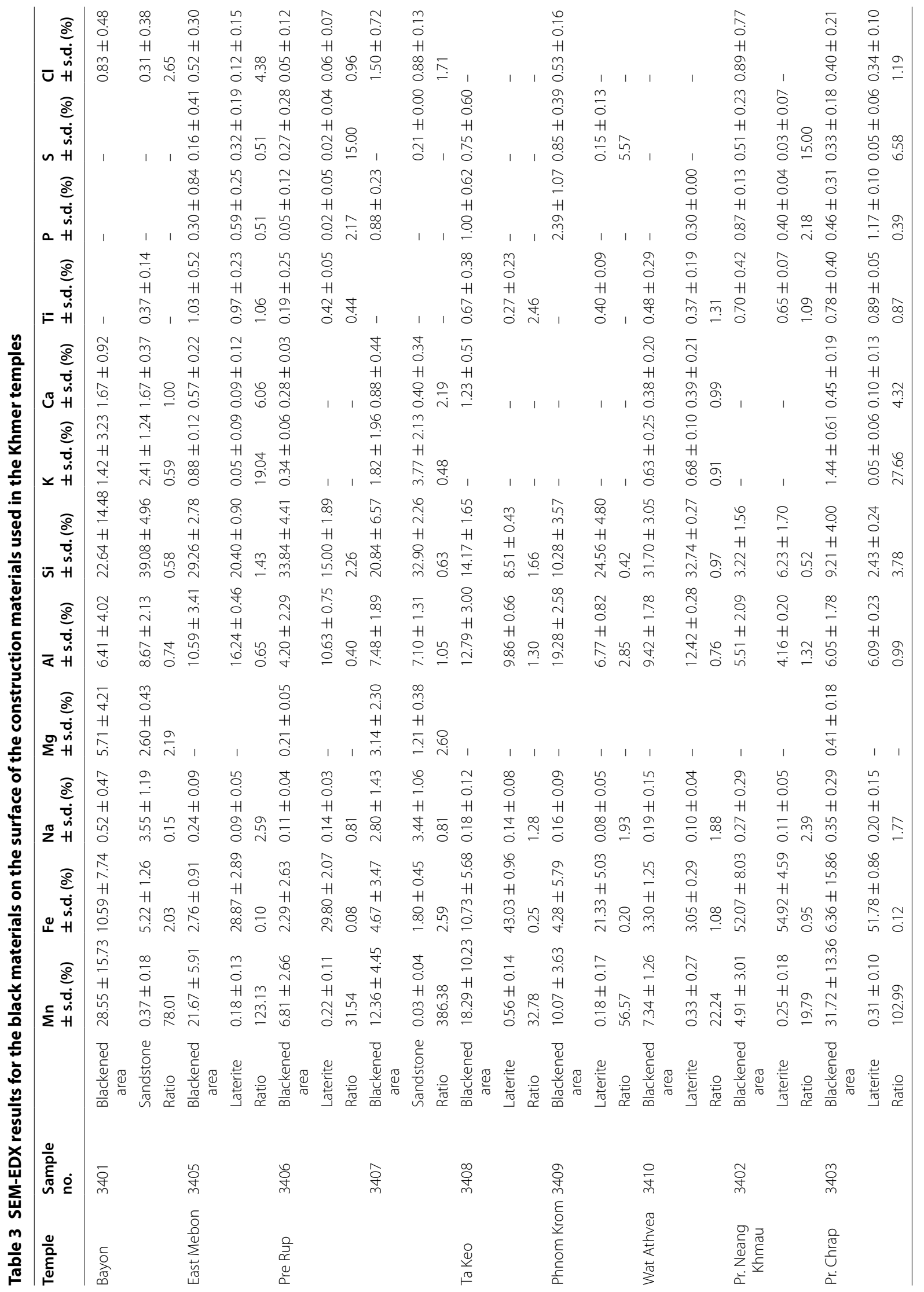




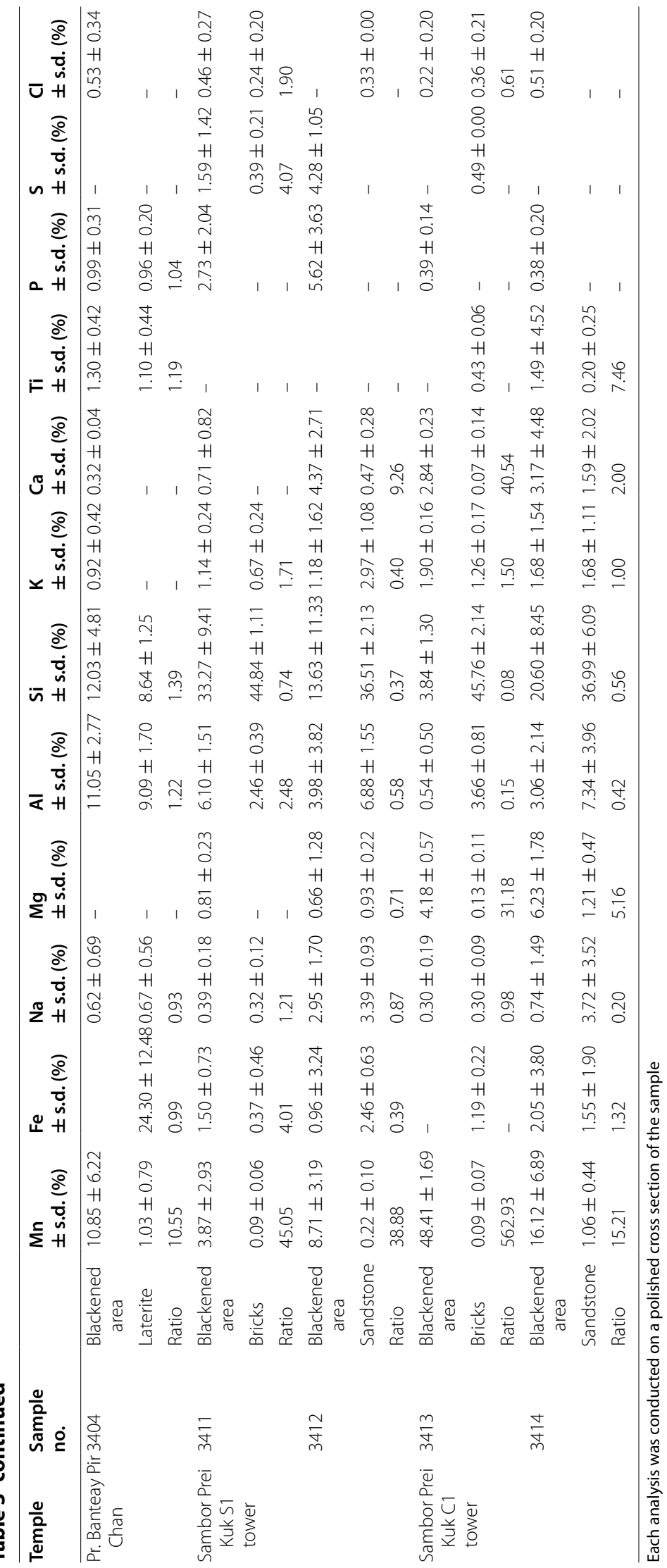


in the black materials under the detection limit of the SEM-EDX.

The concentration ratio of each element in the black area to that in the non-black area is shown in Fig. 5. This figure shows that $\mathrm{Mn}$ was considerably concentrated in the black area. In addition, slightly higher levels of $\mathrm{Mg}$, $\mathrm{Ca}$, and $\mathrm{K}$ were found in the black areas than those in the non-black areas (Fig. 4).

\section{XRD analysis}

The results of the XRD analysis are shown in Table 4.

Quartz, plagioclase, goethite and kaolinite were detected in many of the samples, and could be attributed to the construction materials (sandstone, laterite and bricks). Brushite $\left(\mathrm{CaHPO}_{4} \cdot 2 \mathrm{H}_{2} \mathrm{O}\right)$ was found in the samples from the Sambor Prei Kuk monuments, and could be attributed to bat guano [12, 13]. Typical peaks for manganese minerals were not detected, which suggest the manganese precipitates exist as amorphous materials or nanoscale materials with low levels of crystallization. X-ray peaks corresponding to birnessite $\left((\mathrm{Na}, \mathrm{Ca}, \mathrm{K}) \mathrm{x}\left(\mathrm{Mn}^{4+}, \mathrm{Mn}^{3+}\right)_{2} \mathrm{O}_{4} \cdot 1.5 \mathrm{H}_{2} \mathrm{O}\right)$ and $10 \AA$ manganese oxide minerals were detected in several samples (Fig. 6). The $10 \AA$ manganese oxide minerals could be buserite $\left(\mathrm{Na}_{4} \mathrm{Mn}_{14} \mathrm{O}_{27} \cdot 21 \mathrm{H}_{2} \mathrm{O}\right)$ and/or todorokite $\left((\mathrm{Na}, \mathrm{Ca}, \mathrm{K}) \mathrm{x}\left(\mathrm{Mn}^{4+}, \mathrm{Mn}^{3+}\right)_{6} \mathrm{O}_{12} \cdot 3-4.5 \mathrm{H}_{2} \mathrm{O}\right)$.
It has been shown that buserite will convert to birnessite with dehydration on heating at $105{ }^{\circ} \mathrm{C}[7,14]$. Therefore, the black precipitates that showed X-ray peaks corresponding to $10 \AA$ manganese oxide minerals were heated at $105{ }^{\circ} \mathrm{C}$ in an oven for $24 \mathrm{~h}$ to identify the mineral. After heating, no change in the X-ray peaks was observed. Consequently, the mineral was identified as todorokite. These findings are consistent with studies that have shown birnessite, todorokite, buserite, and vernadite are the major constituents of manganese nodules and crusts on the sea floor [1517]. Birnessite is also the main manganese mineral found in desert varnish [5].

\section{FE-SEM analysis}

Stacks of hexagonal plates ranging in size from 100 to $200 \mathrm{~nm}$ in diameter were common in the samples of the manganese oxide precipitates (Fig. 7). In addition, some of the precipitates showed rod-shaped structures with lengths between 100 and $300 \mathrm{~nm}$. The images for several of the samples showed areas with the rod-shaped structures incorporated into and forming the hexagonal plates. The rod-shaped structures suggest that the precipitation of manganese oxides may have been initiated by the activity of manganese oxidizing microbes. Manganese oxidizing bacteria have also been found in manganese

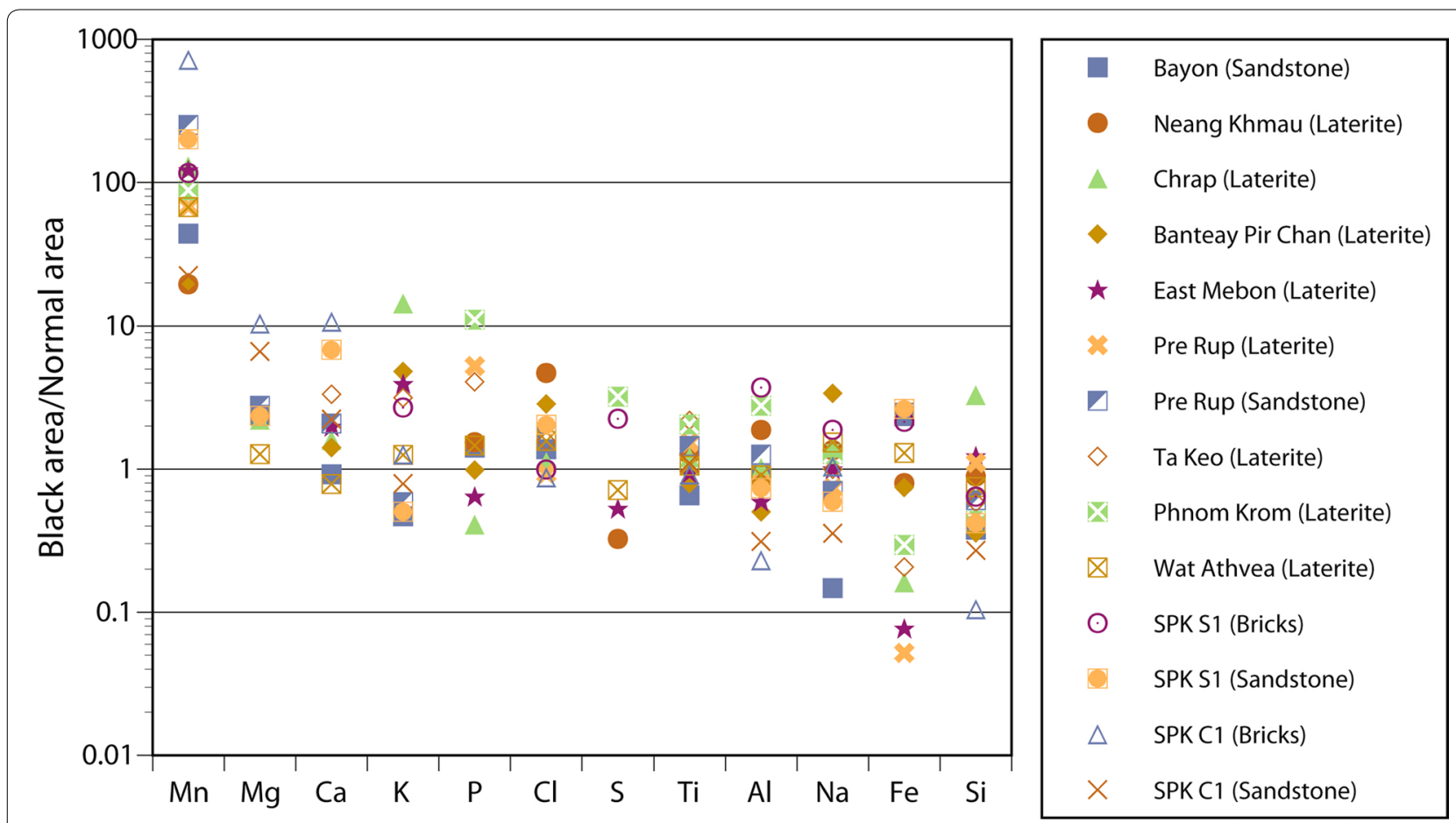

Fig. 5 SEM-EDX results expressed as concentration ratios for elements in the black areas to those in the non-black areas on the surfaces of construction materials used in the Khmer temples 
Table 4 XRD results for the black materials on the surface of the construction materials used in the Khmer temples

\begin{tabular}{|c|c|c|c|c|c|c|c|c|c|}
\hline Temple & Sample no. & Base material & Quartz & Plagioclase & Goethite & Kaolinite & Birnessite & Todorokite & Brushite \\
\hline Bayon & 3401 & Sandstone & O & O & & & O & ○ & \\
\hline Prasat Neang Khmau & 3402 & Laterite & ○ & & O & & & O & \\
\hline Prasat Chrap & 3403 & Laterite & O & & & & & & \\
\hline Prasat Banteay Pir Chan & 3404 & Laterite & & & O & & & & \\
\hline East Mebon & 3405 & Laterite & O & & & O & & & \\
\hline Pre Rup & 3406 & Laterite & O & & ○ & O & & & \\
\hline Pre Rup & 3407 & Sandstone & O & O & & & O & O & \\
\hline Ta Keo & 3408 & Laterite & O & & ○ & O & & & \\
\hline Phnom Krom & 3409 & Laterite & O & & O & O & & & \\
\hline Wat Athvea & 3410 & Laterite & O & & O & O & & & \\
\hline Sambor Prei Kuk: Tower S1 & 3411 & Bricks & O & & & & & & \\
\hline Sambor Prei Kuk: Tower S1 & 3412 & Sandstone & 0 & O & & & O & O & O \\
\hline Sambor Prei Kuk: Tower C1 & 3413 & Bricks & O & & & & & & \\
\hline Sambor Prei Kuk: Tower C1 & 3414 & Sandstone & 0 & 0 & & & 0 & 0 & 0 \\
\hline
\end{tabular}
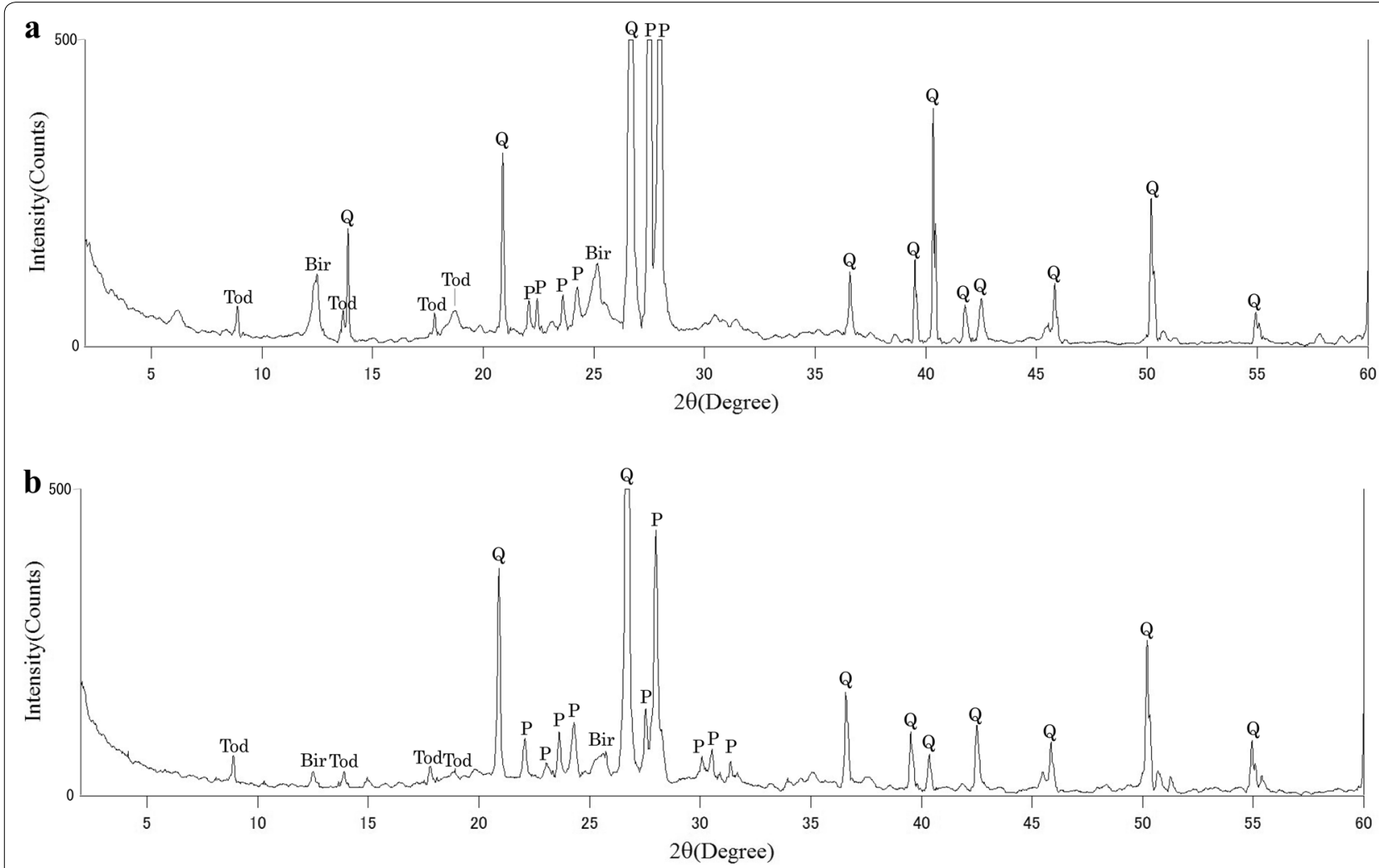

Fig. 6 XRD patterns for the black materials taken from the surfaces of construction materials used in the Khmer temples. a Sample no. 3401 from Bayon (inner gallery), and b sample no. 3407 from Pre Rup. Q quartz, P plagioclase, Tod todorokite, and Bir birnessite

nodules and crusts on the sea floor and in desert varnish $[6,18,19]$. In addition, Hariya and Kanari [20] reported that bacteria caused precipitation of manganese oxides in a spring.
Preliminary experiments on removal of manganese oxide precipitates

The solubility of tetravalent manganese ion is low, but that of divalent manganese ion is high. Therefore the 


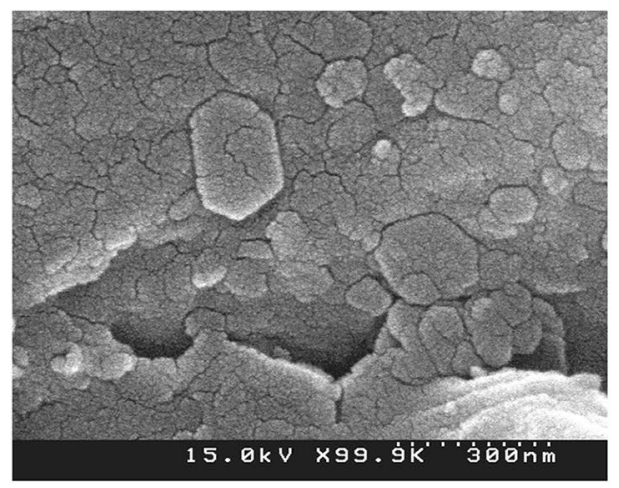

a Bayon, sample No. 3401

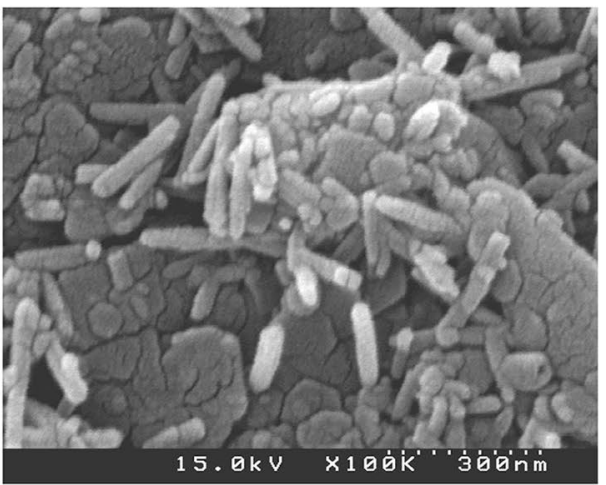

c Pr. Banteay Pir Chan, sample No. 3404

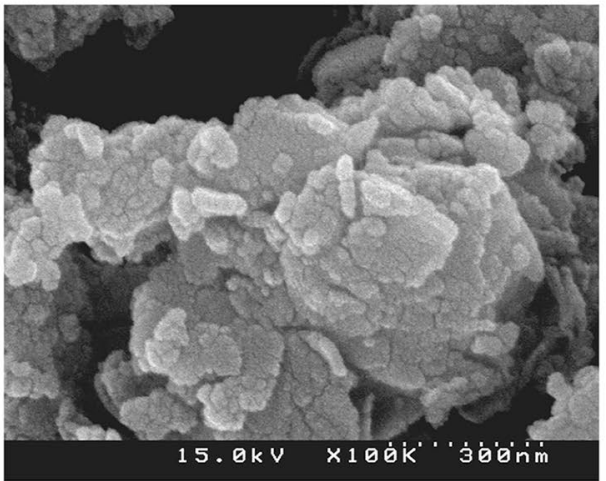

e SPK S1, sample No. 3412

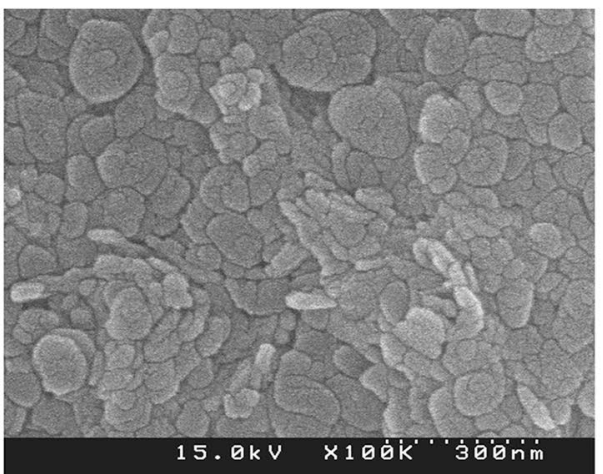

b Pr. Neang Khmau, sample No. 3402

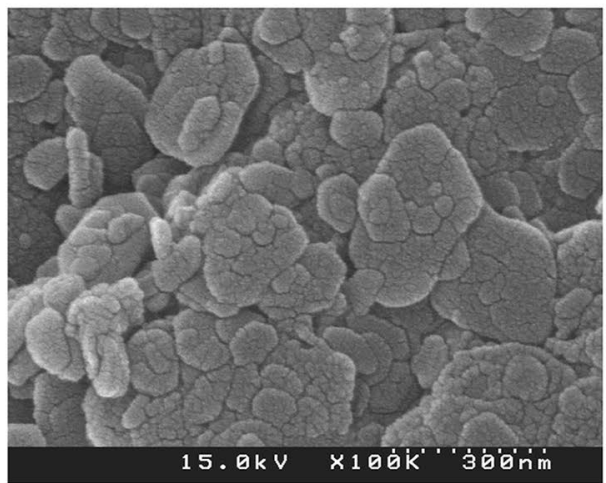

d East Mebon, sample No. 3405

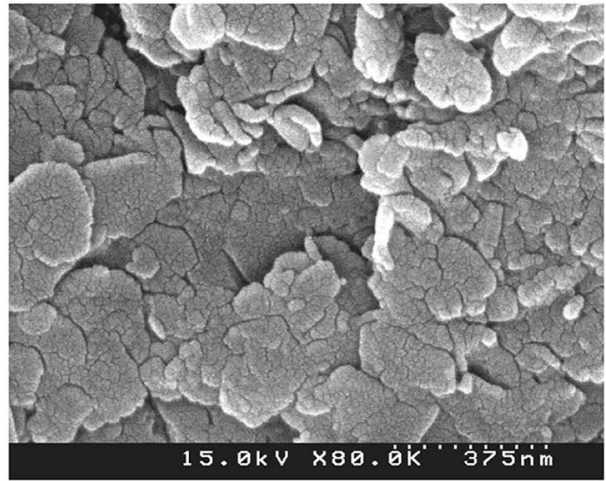

f SPK C1, sample No. 3413

Fig. 7 FE-SEM images of the manganese oxide precipitates on the surfaces of construction materials used in the Khmer temples. $\mathbf{a}$ Sample no. 3401 from Bayon, b sample no. 3402 from Neang Khmau, c sample no. 3404 from Banteay Pir Chan, d sample no. 3405 from East Mebon, e sample no. 3412 from tower S1 at the Sambor Prei Kuk monuments, and $\mathbf{f}$ sample no. 3413 from the tower C1 at the Sambor Prei Kuk monuments

reduction of manganese may be the best method to remove the manganese oxide precipitates on the surface of construction materials.

In this context, we carried out the preliminary experiment on removal of manganese oxide precipitates using an oxalic acid solution with a concentration of $0.1 \mathrm{~mol} / \mathrm{l}$ as a reducing agent. The laterite sample from
Prasat Chrap (sample no. 3615), covered with manganese oxide precipitates was immersed in the oxalic acid solution for $0,1,3$ and $5 \mathrm{~h}$. The photographs of the sample before and after the experiments are shown in Fig. 8 . Almost all manganese oxides disappeared within $3 \mathrm{~h}$ after the immersion into the oxalic acid solution. No visible change of laterite was observed. The same result was 


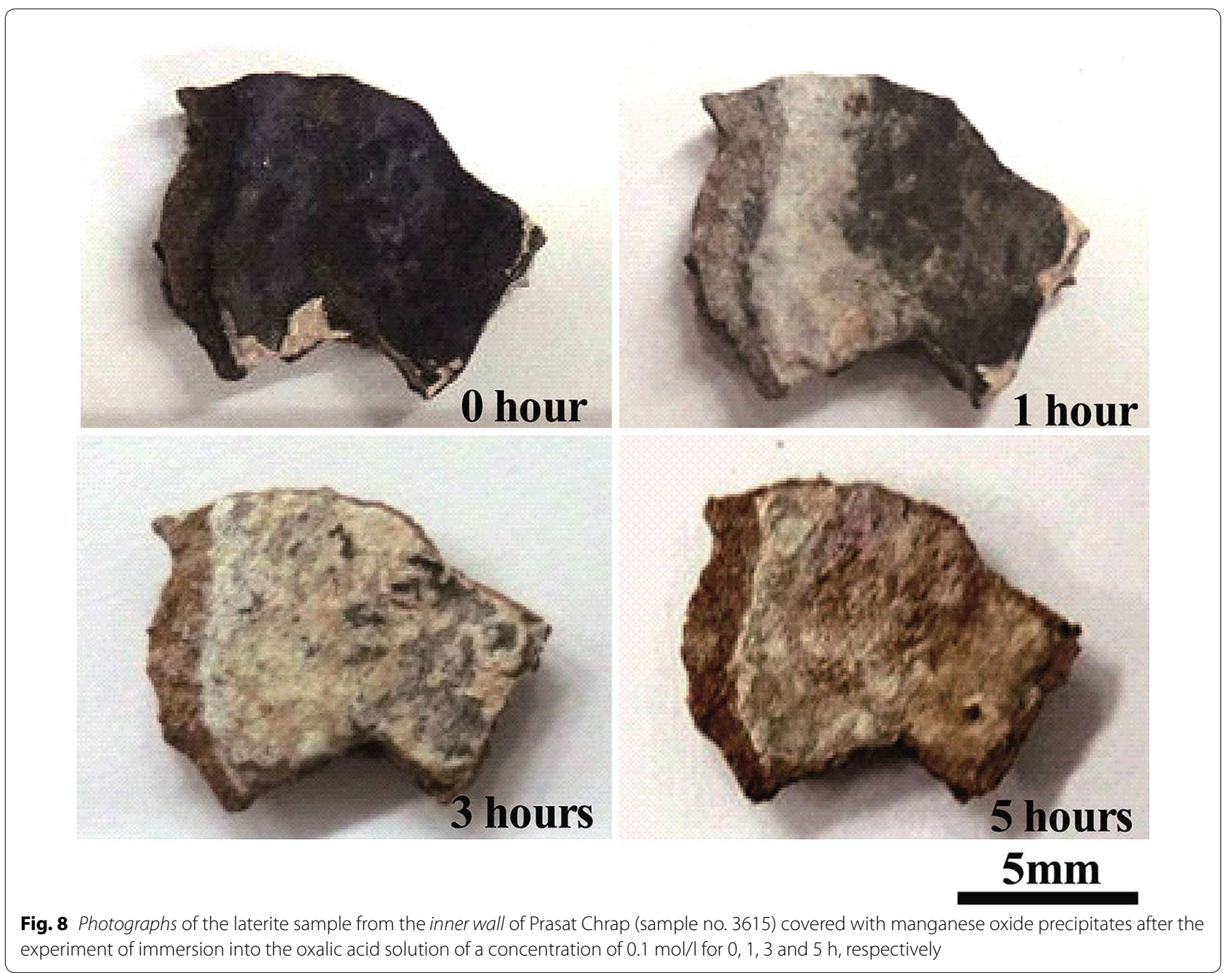

obtained for sandstone covered with manganese oxide precipitates. Therefore the reduction using a reducing agent such as an oxalic acid is a useful method to removal of manganese oxide precipitates.

\section{Conclusions}

Blackening caused by something other than the growth of blue-green algae is frequently observed on the surface of construction materials used in the Khmer temples in Cambodia. The results of this study showed that the black areas are caused by precipitation of manganese oxides. In addition to $\mathrm{Mn}$, the precipitates contain small amounts of $\mathrm{Ni}, \mathrm{V}, \mathrm{Zn}, \mathrm{Y}, \mathrm{K}, \mathrm{Cl}, \mathrm{S}, \mathrm{Pb}$, and $\mathrm{Cr}$. The manganese oxides mainly exist as an amorphous phase, but some are present as birnessite and todorokite. The precipitates are mostly present as hexagonal plates ranging in size from 100 to $300 \mathrm{~nm}$, but some are rod-shaped. This suggests that precipitation of manganese oxides may have been initiated by the activity of manganese oxidizing microbes.
The manganese oxide precipitates could be easily removed using a reducing agent such as an oxalic acid solution.

\section{Authors' contributions}

EU designed this study. All the authors carried out the field investigation. RW and SO conducted the laboratory work. All the authors interpreted data. EU drafted the manuscript. All authors read and approved the final manuscript.

\section{Author details}

${ }^{1}$ Department of Resources and Environmental Engineering, Waseda University, Ohkubo 3-4-1, Shinjuku-ku, Tokyo 169-8555, Japan. ${ }^{2}$ Department of Earth and Planetary Science, The University of Tokyo, Hongo 7-3-1, Bunkyo-ku, Tokyo 113-0033, Japan.

\section{Acknowledgements}

This research was conducted with permission from Authority for Protection and Management of Angkor and the Region of Siem Reap (APSARA National Authority), and was supported in part by a Grant-in-Aid for Scientific Research of the Japan Society for the Promotion of Science (Grant No. 23401001: E. Uchida, No. 25257303: T. Matsui of the University of Tsukuba). We would like to express our gratitude to all the members of JASA for their kind help during the research. 


\section{Competing interests}

The authors declare that they have no competing interests.

Received: 17 December 2015 Accepted: 10 May 2016

Published online: 27 June 2016

\section{References}

1. Uchida E, Ogawa Y, Nakagawa T. The stone materials of the Angkor monuments, Cambodia. The magnetic susceptibility and the orientation of the bedding plane of the sandstone. J Min Pet Econ Geol. 1998:93:411-26.

2. Uchida E, Maeda N, Nakagawa T. The laterites of the Angkor monuments, Cambodia. The grouping of the monuments on the basis of the laterites. J Min Pet Econ Geol. 1999;94:162-75.

3. Arai $\mathrm{H}$, Yamagishi T: Conservation science. In: Japanese Government Team for Safeguarding Angkor, editor. Annual report on the technical survey of Angkor monument 1998, Japan International Cooperation Center, Japan, 1998. p. 393-406.

4. Uchida E, Watanabe R. Blackening of the surfaces of Mesopotamian clay tablets due to manganese precipitation. Archaeol Discov. 2014;2:107-16.

5. Potter RM, Rossman GR. Desert varnish: the importance of clay minerals. Science. 1977;196:1446-8.

6. Potter RM, Rossman GR. The manganese- and iron-oxide mineralogy of desert varnish. Chem Geol. 1979;25:79-94.

7. Dorn Rl, Oberlander TM. Microbial origin of desert varnish. Science. 1981;213:1245-7.

8. Imai N, Terashima S, Itoh S, Ando A. 1994 compilation values for GSJ reference samples, "Igneous rock series". Geochem J. 1995;29:91-5.

9. Uchida E, Tsuda K, Shimoda I. Construction sequence of the Koh Ker monuments in Cambodia deduced from the chemical composition and magnetic susceptibility of its laterites. Herit Sci. 2014;2:1-11.
10. Hein JR, Koschinsky A, Halliday AN. Global occurrence of tellurium-rich ferromanganese crusts and a model for the enrichment of tellurium. Geochim Cosmochim Acta. 2003;67:1117-27.

11. Dorn Rl, Krinsley DH, Liu T, Anderson S, Clark J, Cahill TA, Gill TE. Manganese-rich rock varnish does occur in Antarctica. Chem Geol. 1992;99:289-98.

12. Hosono T, Uchida E, Suda C, Ueno A, Nakagawa T. Salt weathering of sandstone at the Angkor monuments, Cambodia: identification of the origins of salts using sulfur and strontium isotopes. J Archaeol Sci. 2006;33:1541-51.

13. Uchida E, Ogawa Y, Maeda N, Nakagawa T. Deterioration of stone materials in the Angkor monuments, Cambodia. Eng Geol. 1999;55:101-12.

14. Usui A, Mellin TA, Nohara M, Yuasa M. Structural stability of marine $10 \AA ̊$ manganates from the Ogasawara (Bonin) arc: implication for low-temperature hydrothermal activity. Mar Geol. 1989;86:41-56.

15. Giovanoli R, Feitknecht W, Fischer F. Uber oxidhydroxide des vierwertigen Mangans mit Schichtengitter, 3. Mitteilung: reduktion von Mangan (III)manganat (IV) mit Zimtalkohol. Helv Chim Acta. 1971;54:1112-24.

16. Burns RG, Burns VM, Stockman HW. A review of the todorokite-buserite problem: implications to the mineralogy of marine manganese nodules. Am Mineral. 1983;68:972-80.

17. Usui A, Someya M. Distribution and composition of marine hydrogenetic and hydrothermal manganese deposits in the northwest Pacific. In: Nicholson K, Hein JR, Bühn B, Dasgupta S, editors. Manganese mineralization: geochemistry and mineralogy of terrestrial and marine deposits. London: Geological Society of London Special Publication No. 119; 1997. p. 177-98.

18. Wang W, Müller WEG. Marine biominerals: perspectives and challenges for polymetallic nodules and crusts. Trends Biotechnol. 2009;27:375-83.

19. Wang $X$, Zeng L, Wiens M, Schloßmacher U, Jochum KP, Schröder HC, Müller WEG. Evidence for a biogenic, microorganismal origin of rock varnish from the Gangdese Belt of Tibet. Micron. 2011;42:401-11.

20. Hariya Y, Kikuchi T. Precipitation of manganese by bacteria in mineral springs. Nature. 1964;202:416-7.

\section{Submit your manuscript to a SpringerOpen ${ }^{\odot}$ journal and benefit from:}

- Convenient online submission

- Rigorous peer review

- Immediate publication on acceptance

- Open access: articles freely available online

- High visibility within the field

- Retaining the copyright to your article

Submit your next manuscript at springeropen.com 